\title{
PORT REORGANISATION REVEALING EAST-WEST DIFFERENTIATION IN THE BALTIC SEA REGION
}

\author{
ARNAUd SERrY ${ }^{1}$ \\ Le Havre Normandy University (France)
}

\begin{abstract}
The Baltic Sea Region (BSR) appears as a specific space in which ports, maritime transport and the entire shipping cluster are crucially important. The BSR is one of the most heavily trafficked seas in the world, and maritime transport has contributed to its prosperity. After the collapse of the USSR, the Baltic Sea recovered its role as a contact and transit area. The opening up of the eastern shore to the market economy has brought about the reactivation of its maritime system, which over the years never stopped being a major element in the production of regional integration. Discourses on Baltic unity are often based on the importance of maritimity and maritime trade, but there is also a significant regional diversity in the shipping industry. Nowadays, the emergence of new directions in specialisation, and of new decision makers in ports, allows for new expectations and issues for Baltic ports. The author shows how, in this special Baltic context, ports and maritime stakeholders interact, participating in regional development and integration, but also by pursuing differentiated trajectories.
\end{abstract}

KEY WORDS: Baltic Sea, ports, maritime transport, regionalisation, differentiation.

JEL CODE: N74.

DOI: https://doi.org/10.15181/rfds.v35i3.2276

\section{Introduction}

'It is difficult to give an unambiguous definition of the Baltic Sea region since it is heterogeneous in terms of language, religion, culture, and history, and is highly diversified in terms of the environment and the economy' (Klemeshev et al., 2017). About 65 million people live fewer than 300 kilometres from the shores of the Baltic Sea. The Baltic region is a diverse one, and questions are raised when attempting to define it: nine different languages are spoken along the coasts, religious traditions vary from one territory to another, and the levels of economic development are relatively mixed. Furthermore, the tumultuous history of the region has weighed heavily on the relationships that the indigenous populations have fostered with their neighbours. However, as early as the 18th century, the Baltic area was already a very active economic zone (Pourchasse, 2010).

At the beginning of the 21 st century, the Baltic space has completed its reconfiguration, after a movement which led its eastern border to extricate itself, as far as possible, from the Russian sphere of influence, to enter fully into Western dynamics. Nowhere else in Europe have there been so many political and economic changes over the past years. The breaking up of the Eastern Bloc has, to a certain extent, unified an area that was crossed just a short time ago by the Iron Curtain (Marcadon, 1998).

The Baltic's maritime dimension is widely perceived as being a factor of unity in itself, and the same natural constraints create a determinism for ships and men, as is clearly summarised by: 'The common bond between the Baltic countries is the sea' (Marcadon, 1998). The role of maritime transport confers regional particularities on the Baltic Sea, among which is the idea that it might contribute strongly to a political regionalisation.

\footnotetext{
Arnaud Serry - doctor, associate professor at Le Havre Normandie University, France

Research interests: social geography, ports

E-mail: arnaud.serry@univ-lehavre.fr; serryarnaud@gmail.com

Tel. +33232744169
} 
The Baltic, Scandinavian and Polish ports are part of a larger system, and create links in the Baltic space. Indeed, the development of the ports and the evolution of maritime traffic are indicative of economic and territorial changes, owing to their interactions in a system affected both by complementarity and growing competition.

In this context, this paper proposes to draw out the specificities of the Baltic port and maritime world, particularly from the question of Baltic unity regularly represented by maritime activities. Firstly, the question of the Baltic Sea as a framework for the development of maritime transport is addressed, and then its global progression in the region. Finally, a change of scale qualifies maritime and Baltic port homogeneity, and shows the omnipresent territorial differentiations.

\section{The Baltic Sea, a framework between homogeneity and complexity}

For many centuries, navigation routes have united peoples living around the Baltic Sea (Mezhevich, Kretinin, Fedorov, 2016). Sea transport is the central connecting link in the Baltic transport region.

\subsection{A specific enclosed sea}

The Baltic Sea, an enclave within the European continent, is one of the largest brackish water systems in the world, in which the distances from coast to coast rarely exceed 150 kilometres. In relation to the Baltic Sea, Nathalie Blanc-Noël mentioned 'a restrictive geographic context' (Blanc-Noël, 1992), which presents several particularities that are not found elsewhere. Firstly, it is a young sea, with a remarkable geological history.

Moreover, owing to the extreme variability of the hydro-physical conditions which reign in the Baltic, specific biotopes, as well as fauna and flora, have developed there. This explains the great vulnerability of the marine ecosystem, on which any disturbance to the environment due to human activity, including that linked to transport, can have seriously harmful effects. Therefore, the assessment of the progression of eutrophication is very alarming. Less than a century ago, the Baltic Sea was a clean sea, low in nutrients. In a short space of time, because of the intensity of discharges of nitrogen and phosphorus, it has become a sea rich in nutrients, and one of the most polluted seas in the world.

The Baltic Sea, therefore, presents an appearance of a closed sea communicating with the exterior by a system of straits. For over four centuries, these straits have given rise to Denmark's perception of a right of way for merchant vessels. Maritime (transit) navigation and harbour issues are at the very heart of the problematic, even if the Baltic, distanced from maritime mega-movements, owing to the physical constraints that are the straits, is a zone of a predilection for coastal navigation (Marcadon, 2004).

The latest access to the Baltic, originally built to facilitate the movement of the military fleet, is the Kiel Canal, which is 98 kilometres in length. It is only 13 metres deep, which reduces the size of ships able to transit through it $(25,000$ DWT) and thus its current economic role, all the more so as it is located in German territory. However, it saves 200 to 400 miles from the ship's route around the Jutland peninsula (Marcadon, 1999), making an average transit time of seven to eight hours, including transiting locks.

Physical features of the Baltic Sea are considered to be the first factors of unity, as is illustrated by the role of the freezing over of the sea in winter, and the economic consequences on port activities. This apprehension goes even further, since the criterion of participation in the Council of Baltic Sea States (CBSS) is itself physical: that of the river basins flowing into the Baltic.

The combination of increased maritime transport and the sensitivity of the Baltic Sea (Vaneeckhaute, Fazlia, 2020) makes it necessary to establish efficient cooperation tools. The sea-environment has been the subject of a great number of cooperative projects, and has, to a certain extent, led to the emergence of transnational cooperation from the Helsinki Convention. 


\subsection{Differing assessments of the Baltic Sea}

Nevertheless, there is no clear consensus regarding the Baltic Sea's maritime borders (Fig. 1). It can be defined without any straits (Variant 1). However, for practical drives, the straits are often considered as being part of the Baltic. Therefore, opinions differ regarding the positioning of the demarcation line between the Skagerrak and the Kattegat (variants 2 and 3), and sometimes the Baltic even includes the Skagerrak partly or totally (variants 4 and 5) (Klemeshev et al., 2017).

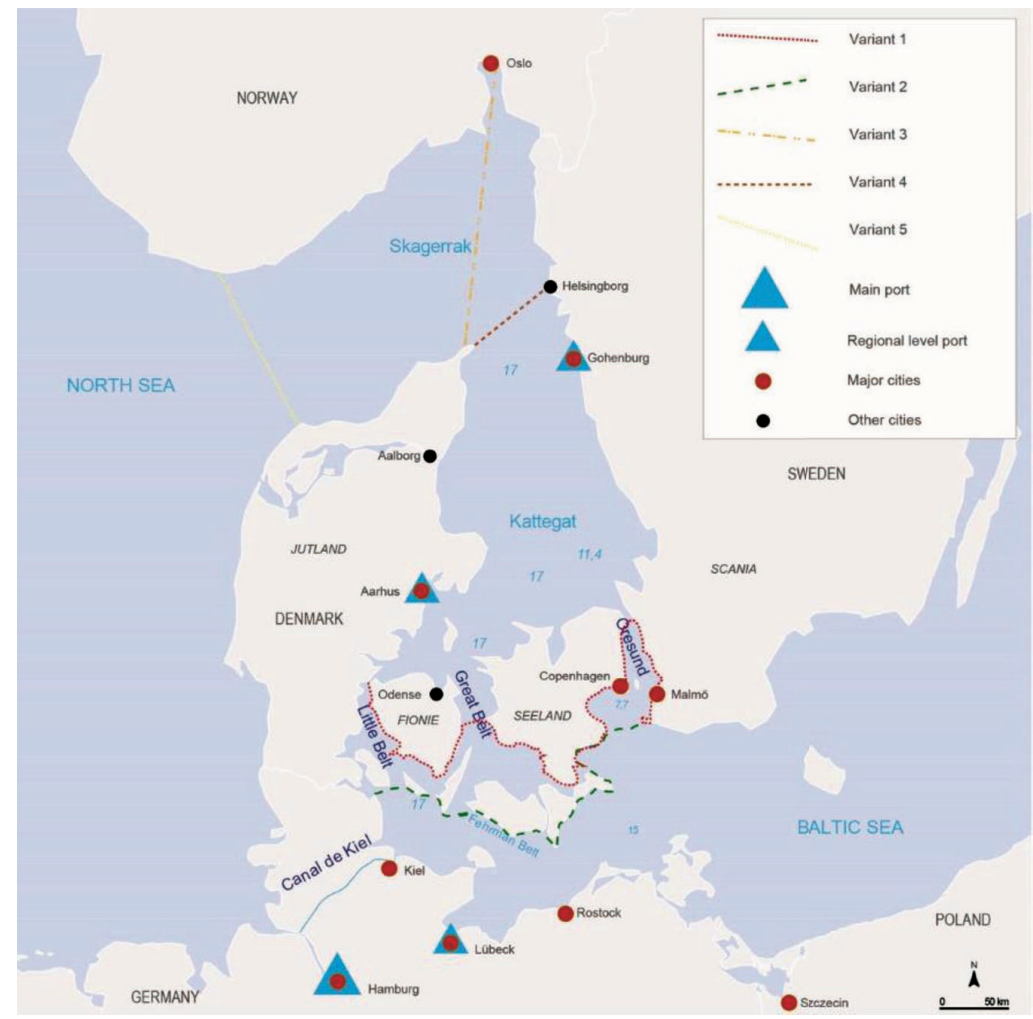

Figure 1. The Danish straits and maritime borders of the Baltic Sea

Source: compiled by the author according to Klemeshev \& al. (2017).

Be that as it may, on its shores it is variably perceived, as is illustrated by the following denominations chosen by the different coastal states, underlying the ambiguity: Österjö in Swedish and Østersø in Danish, meaning literally 'East Lake'; but Läänemeri for the Estonians, or 'West Sea'. It is also called Ostsee (East Sea) by the Germans, who for a long time made it a Binnenmeer, an 'inland sea', which for them was intended to be a German lake (Chillaud, 2019). It is referred to as the Baltic Sea in Latvian (Baltijas jura) and in Lithuanian (Baltijos jura), as in Russian (Baltiïskoe more) and Polish (Morze Bałtyckie). Beyond denominations, these differences highlight the fact that the Baltic Sea does not have a visible regional identity, and that the space is variably seen as having an open or closed character.

The Baltic region is a major example of this geographical 'between two', and is frequently considered in isolation, without placing it in a wider geographical context, as well as in the historical and political context of its emergence. Baltic regionalisation, long limited to the deconstruction of the east/west border, is nevertheless constituted of simultaneous interactions on several scales of spaces (Joenniemi, Kukk, Jervell, 1992). Moreover, the raison d'être of Baltic stakeholder networks is in line with the dynamics belonging to multiple geographical levels, which reinforces the intermediary dimension of the Baltic space (Escach, Vaudour, 2014). 
What emerges from the above lines is the existence of different perceptions regarding this maritime space. The open or closed representation of the Baltic Sea held by the different countries bordering the Baltic space is effectively not without consequence with respect to the strategic and economic perception they have of it. It is also the idea of a constrained and constraining traffic zone, a maritime cul de sac, certainly real, but which needs to be qualified. Of course, in the Baltic, by sea, you can at best thrust into the Gulf of Bothnia or the Gulf of Finland, but the same Baltic can constitute a western escape route to territories heavily influenced by continentality. This cul de sac also corresponds with an almost mandatory transit route for certain types of traffic, which in effect makes it a catchment area for east-west and north-south flows. Despite these many disadvantages, like the shallow depth of the straits, which prevents the passage of giant ships, due to its situation inside the European continent, the Baltic has attracted the interest of adjacent societies. For many years, it was a major communication channel of the Norden, more frequented than land routes. Moreover, it has long had the reputation of being a vibrant maritime artery of international importance. Every large city has its port. It therefore claims to be a space linking its shores with the spaces beyond them.

\section{Maritime transport: a revealing and driving force of Baltic territorial reorganisation}

\subsection{Port traffic: sharing the growth}

Seaborne trade has doubled over the last two decades across the world, going from $400 \mathrm{Mt}$ to over $860 \mathrm{Mt}$, i.e., a greater increase than that of world maritime traffic. This development is primarily the consequence of profound geopolitical changes in the region, which have reopened the eastern shore to the market economy and free trade, enabling the development of new traffic.

Rapid adaptation and modernisation, together with the restructuring of the regional port tool, have, furthermore, greatly contributed to this growth, which seems to be the principal characteristic that the Baltic port community has in common, be they Nordic, Baltic or Russian ports (Fig. 2).

The general growth in maritime activity in the region illustrates the role of point of contact that is regularly assigned to maritime transport, which is thus one of the pillars of the development of the economy, catchment areas and the internationalisation of trade.

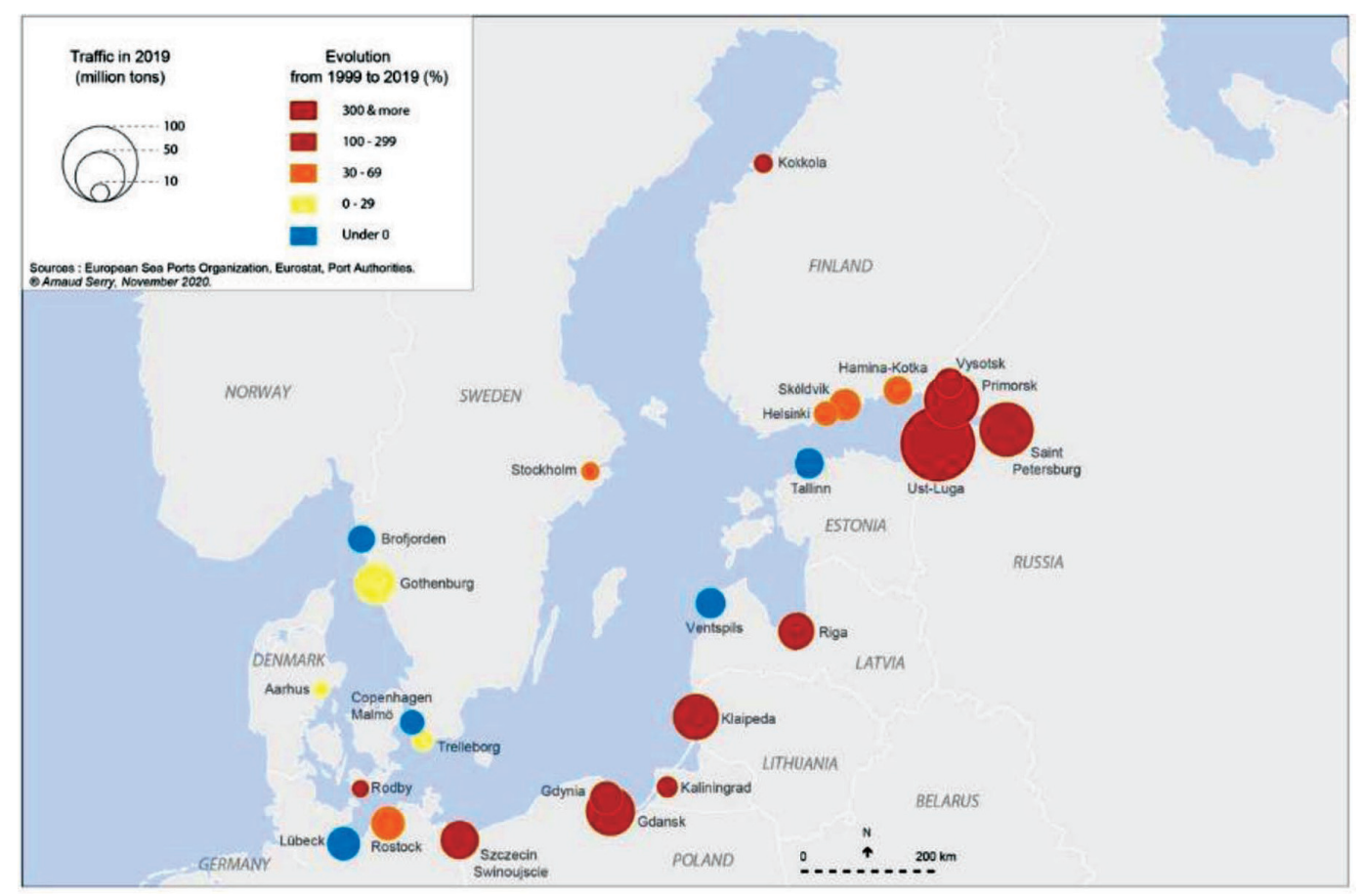

Figure 2. The main Baltic ports in 2019 and their evolution 
There are numerous examples of this general growth in the region. Indeed, the flows are very diversified, going from bulk liquid, notably Russian oil, to the traffic of passengers taking the many ferries plying the region, through to the increasing number of container ships skimming the Baltic. So the Baltic Sea is highly diversified, both in terms of ship types operating within its waters, and ports found along its shores (Czermański, 2017).

Yet there is one example, with its recent, original character, that sheds a particular light on the situation. The sea cruise industry in the Baltic is developing rapidly, and is growing especially fast. It was formerly a secondary activity, but is now becoming highly prized by ports and port cities. It is taking advantage of the robust development of this form of tourism in Europe since the beginning of the 2000s, and now represents over $10 \%$ of the European total.

More generally, along with the global growth in traffic, maritime flows have seen a category redistribution in favour of hydrocarbons and containers, which now make up the main part of the tonnage handled, next to the Baltic roll-on/roll-off specificity and flows of dry bulk which are still considerable. As a result, the Baltic is equipped with an excellent network of passenger transport: around 30 million people travel by ferry each year. This linkage participates fully in regional economic development, as well as the integration of the different shores.

\subsection{Regionalisation of maritime flows}

AS heir to a specific configuration regarding the world maritime economy, the Baltic Sea today is still indirectly connected to the great maritime routes serving the large world ports, in Europe, those of the Northern Range (the seaboard from Le Havre to Hamburg). The Baltic is served from these pivotal ports via less important maritime services called 'feeders'. ${ }^{2}$ Hence, 'large' container ports are rare, all the more so as the 'cul de sac' effect limits commercial and operational opportunities for these ships' turnaround. Whether it is a question of ports on the western shore or others, direct relations with ports outside the European Union are rare or even non-existent. Baltic regionalisation is being set in motion via the concentration of maritime links in the ports of Hamburg and Bremerhaven. The economic openness of the Baltic space manifests itself paradoxically in the shrinkage of the ports' foreland: the forelands of all the ports in the region are refocusing on the ports of northwest Europe.

A study of maritime circulation in the Baltic Sea can distinguish three categories of maritime route:

- Intra-Baltic routes dominated by links between Nordic ports and western ports in the region, i.e., Danish and German. As early as 1998, intra-Baltic coastal navigation represented almost half of port traffic. This explains the activity of the large number of ports along the coasts.

- Containerised services linking the Baltic ports with the major ports of Western Europe, then by transhipment to the rest of the world. Container flows in the Baltic Sea were growing roughly in line with the worldwide market until 2014 (Serry, 2019), but growth slowed down a little because of the Russian economic crisis. Today, regional hubs are emerging, such as the port of Gdansk (Fig. 3). The cargo turnover of Gdansk rose almost 16 times between 2005 and 2015.

- maritime connections by tramping (a shipping service which, contrary to regular lines, is not scheduled in advance); mainly dedicated to Russian bulk, which connects the Baltic directly with overseas ports.

Certain circulations are symptomatic of Baltic maritime heterogeneity, like agricultural flows, which concern chiefly the east Baltic ports.

A 'feeder ship' is a small-tonnage ship, enabling cargo shipped to a main port by a large ship not calling at many ports to be broken up and shipped to different short-distance ports. Conversely, it ships freight collections to the main port. 


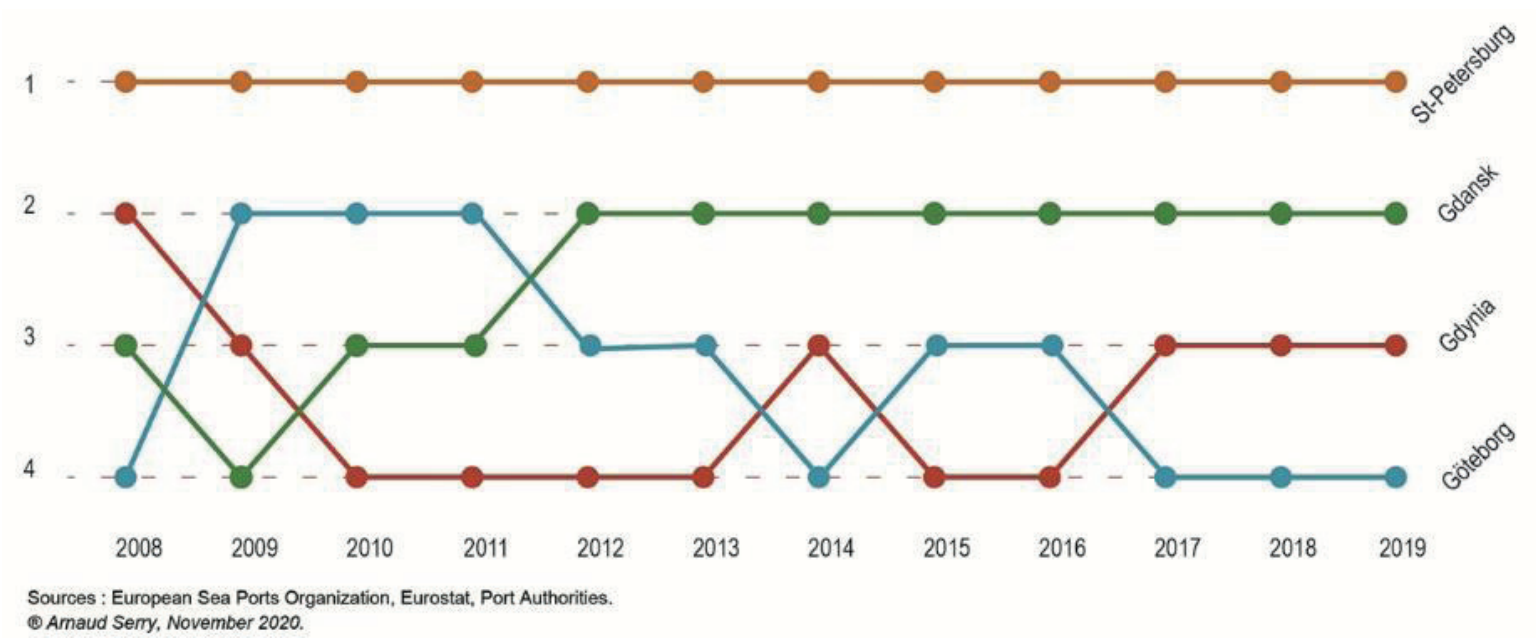

Figure 3. The evolution in the positions of the four principal container ports

Furthermore, reorganising the flows in the region is materialised through the development of new infrastructures. There are numerous building developments or port expansions, but they are on a larger scale in former communist countries: the most ambitious ones are located above all in Russia, which has had to replace the capacity of the Soviet ports that have become Baltic ports. In addition, if in general investors in Baltic countries are mainly Swedish, German, Norwegian, Finnish and Danish, this is not the case at all in the port environment where they are mostly Russian, Belarusian or global stakeholders from the maritime world.

\section{Ports in the Baltic Sea rather than Baltic ports}

\subsection{Spatially differentiated port dynamics}

A close examination of maritime circulation and port traffic highlights growth which is in reality unevenly distributed: port traffic is generally brisker in the east Baltic than in Scandinavia.

Different economic strategies can be found in the organisation of the Baltic maritime space. They are mainly connected with the types of cargo. So the Nordic ports, with the exception of Gothenburg, are essentially ports providing regional or national maritime services. Traffic in these ports is often modest, but should not minimise their role in regional economies, especially for the 'faraway' regions, the Gulf of Bothnia, for example.

The ports of the southern rim are of two types:

- German ports, close to the straits, are medium-sized ports, dominated by north to south ro-ro flows. This is also the case for most Danish ports.

- As for the Polish ports, they are experiencing rapid change, oscillating between medium-sized ports with an essentially national vocation, and intermediate shipping hubs. As a result, Gdansk is the only Baltic port to be integrated into a Europe-Asia service. It is now in second position in the region behind St Petersburg, and competes strongly with Gothenburg, which has benefited for a long time from its location outside the Danish straits. Lastly, the Gulf of Gdansk ports as a whole (with Gdynia) are in first position, with over 2.9 million TEU in 2019.

On the eastern shore, the Soviet authorities organised the export of many products by a system of pipelines and port terminals, all involving transit via western republics and leading to Baltic ports (Radvanyi, 2017). So the Baltic countries have not ceased to be the seaboard for Russia and Belarus (Drweski, 2006). This is also more or less the same for some Finnish ports, even if most of them have a role to serve the domestic territory, with its strong insular character. 
Russia has recently decided to provide itself with a new port capacity, in order to control and capitalise on these international exchanges, reducing its dependency on what have become foreign ports, by completing the existing pipeline network, and developing new port terminals connected to the rail network, notably Vyborg and Primorsk for hydrocarbons, and Ust-Luga for other cargo. Within this framework, the port of Kaliningrad has effectively become marginal, owing to its isolation from Russian territory and the new container terminal which has been developed, essentially serving companies in the local free economic zone. Regarding the port of St Petersburg, it is too hemmed in by its agglomeration, and should refocus on passenger traffic and some specialised transport (Radvanyi, 2017).

In fact, the share of transit has not radically diminished, despite cyclical variations according to the type of commodity. Russian interests continue to establish themselves in the ports of Baltic countries (Thorez, 2011), but there are few investments coming from the west Baltic.

\subsection{From the myth of maritime unity to reality?}

Ro-ro traffic is commonly considered as a particularity of the Baltic Sea, as well as integrating with its adjacent spaces.

Intra-Baltic connections use ro-ro ships and ferries, hence the relative importance of passenger traffic. Talking about this ro-ro maritime network, run by powerful companies, is therefore relevant in the region. Ordinarily, it is simplistic to explain the spatial integration between the Baltic shores by means of ro-ro lines. Among the intra-Baltic links, many lines concern local lines, especially by ro-pax ships. Ultimately, there are few transnational links, and they concern mainly ports of the east Baltic (Klaipeda, Liepaja, Ventspils, Riga), or ports of the German coast, like Lübeck, Travemünde or Kiel. In fact, the principal transnational connections chiefly link German ports to the Baltic or Gulf of Finland ports using a west to east logic.

A typology of ro-ro links confirms that a small number of ports are dependent on the Baltic range. Most of the ro-ro connections therefore operate locally, notably around the Øresund and the region around the Gulf of Finland. Slightly less than a third of the ro-ro lines are transnational, about a quarter are bound for ports outside the Baltic (Escach, Serry, 2013). This reality partly debunks the myth of ferries reflecting a unified Baltic space: moreover, although there is a dense interconnection of the network in the Danish straits and the south Baltic, it tends to loosen particularly between the Nordic countries and the Baltic States. The Scandinavian countries are historically interconnected by a diversity of maritime services, as is proven by the intensity of ro-ro services in the Danish straits. But the lines leaving the eastern Baltic provide services bound essentially for Denmark and Germany, i.e., towards Western Europe, and their essential role is to transport freight rather than people.

Among the main features defining the dynamic of maritime traffic in the Baltic Sea, an increase in flows of hydrocarbons has emerged, fuelled largely by the development of Russian exports.

In 2019, bulk liquid represented over 280 million tonnes, i.e., almost $35 \%$ of the volumes handled in the regional ports.

Today's Russian legislation motivates ship owners and cargo owners to use the Russian ports (Efimova, 2019). So after having benefited the Baltic ports, this captive traffic was re-directed to the Russian ports.

On the other Baltic shores, the situation is quite different. If the flow of hydrocarbons constitutes considerable volumes of traffic in certain Scandinavian ports, like Brofjorden in Sweden, or Sköldvik in Finland, it is mainly import flows responding to domestic needs. There is an obvious dichotomy between the Nordic ports, which are market ports, mainly for imports, supporting west-to-east flows, and the Russian and Baltic ports, with a global role of exporting oil flows from east to west.

The gas pipeline configuration in the region explains the Baltic dependency on Russian gas deliveries. But the Baltic ports have shown a heightened interest in liquefied natural gas (LNG) installations (Rozmarynowska, 2012), and there is a battle for LNG terminals. From 2014 to 2016, four LNG import terminals were deployed in Lithuania, Poland, Finland and Sweden (Fig. 4). 


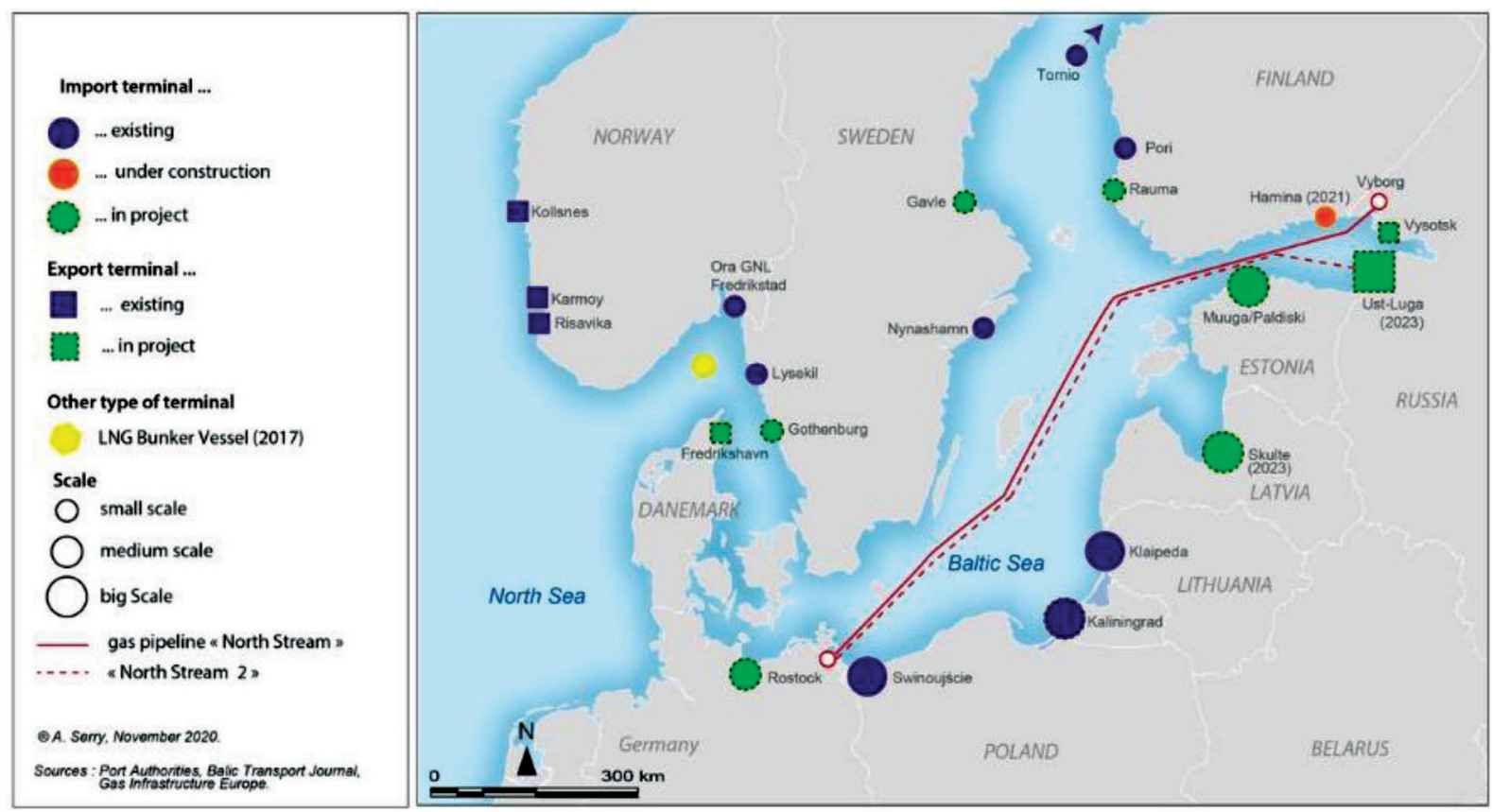

Figure 4. The development of LNG in the Baltic Sea

In reality, one main driver guides the development of LNG installations in the Baltic: LNG is considered to be a means of moving away from reliance on Russian energy, by diversifying gas supplies and enabling more flexibility (Liuhto, 2013).

The Baltic maritime space also appears to be particularly favourable to the development of LNG maritime propulsion technology. Geography is involved in the organisation of regional proximities affected by the maritime phenomenon, and especially by regular ferry links (Beyer, 2019).

LNG flows, just like the building of specialised terminals, reinforce the dichotomy between the eastern and the western seaboard. Baltic and Russian development projects are predominantly carried by geopolitical or macro-economic considerations (Gritsenko, Serry, 2015); whereas for the time being, Nordic and Scandinavian projects are instead designed on a local scale, the first aim of which is economic, either to reduce the import costs of gas, or to enter the LNG market as maritime fuel.

The role of Russia is particularly important, since in Baltic LNG dynamics, Russia is a 'dual' key stakeholder: both a regional supplier and a world stakeholder in the production of gas. Hence Russian installations are major developments for the region, even if on a global scale they are still relatively modest, and possibly in competition with the development of Arctic solutions, chiefly at Sabetta.

\section{Conclusion}

The sea as a support for maritime trade is undeniably a common feature of the countries in the Baltic space, where maritime and port activities have experienced a certain dynamism over the past 20 years. Acknowledgement of the maritime phenomenon, of its economic importance, often vital for local economies but also for its impact, therefore constitutes a common denominator on the shores of the Baltic.

Nevertheless, whether it is a question of the type of traffic, the mode of port governance, the functions (transit port, trans-shipment), or their weight in the local economy, there are many differences between the region's ports. Closer ties between the shores are achieved less by traffic between the shores than by their insertion into structured networks around major poles of global maritime transport. If sub-regionalisation is relevant: the Danish straits, the eastern port range or again the southern Baltic ports, contemporary port 
reorganisation in the region strengthens the positioning of ports in the context of globalised maritime trade, rather than in regional integration supported by the sea.

Maritime and port activity in the limited space of the Baltic is affected more by competition than by complementarity, by multi-scale analysis rather than regional homogeneity. Hence the Baltic ports, which are relatively large in size in the Baltic context, strongly concerned with the transport of Russian raw materials, are very different from the Nordic or Swedish ports, which are small in size, and oriented towards their domestic markets. The traffic characterised by the omnipresence of Russia mainly in energy flows appears likely to weigh heavily on regional economic dynamics, just as on regional and geopolitical diplomacy on this eastern border between the European Union and the Russian Federation.

\section{References}

Beyer, A. (2019). Les enjeux portuaires de l'adoption du GNL comme carburant Contextes, projets et stratégies des acteurs portuaires. Report for the SEFACIL fundation.

Blanc-Noël, N. (2003). La Baltique. Une nouvelle région en Europe. Paris: L'Harmattan, 174 p.

Chillaud, M. (2019). L'espace Baltique entre périls stratégiques et angoisses sécuritaires. Stratégique, Vol. 121-122, p. $15-59$.

Czermański, E. (2017). Baltic Shipping Development in Maritime Spatial Planning Aspect. Studia i Materiały Instytutu Transportu i Handlu Morskiego, Vol. 14, p. 48-63.

Drweski, B. (2007). L'espace Baltique-mer Noire. Strates, Vol. 12. Available at: http://strates.revues.org/1902 [accessed 3 September 2020].

Efimova, E., Vroblevskaya, S. (2019). Are Eastern Baltic Ports the drivers of Eurasian trade? International Journal of Management and Economics, Vol. 55(3), p. 1-14.

Escach, N., Serry, A. (2013). Les ports de la Mer Baltique entre mondialisation des échanges et régionalisation réticulaire. Géoconfluence. Available at: http://geoconfluences.ens-lyon.fr/test/doc/transv/Mobil/MobilScient7.html [accessed 29 October 2020].

Escach, N., Vaudor, L. (2014). Réseaux de villes et processus de recomposition des niveaux: le cas des villes baltiques. Cybergeo: European Journal of Geography. Available at: http://journals.openedition.org/cybergeo/26336 [accessed 2 November 2020].

Gritsenko, D., Serry, A. (2015). A geographical perspective on LNG facility development in the Eastern Baltic Sea. In A. Weintrit, T.Neumann (eds.). Marine Navigation and Safety of Sea Transportation. CRC Press, p. 153-160.

Joenniemi, P., Kukk, M., Jervell, S. (1992). The Baltic Sea area, a region in the making. Oslo: Europa-Programme in cooperation with the Baltic Institute, $241 \mathrm{p}$.

Klemeshev, A. P., Korneevets, V. S., Palmowski, T., Studzieniecki, T., Fedorov, G. M. (2017). Approaches to the definition of the Baltic sea region. Baltic Region, Vol. 9(4), p. 4-20.

Liuhto, K. (2013). Liquefied Natural Gas in the Baltic Sea Region. Journal of East-West Business, Vol. 19(1-2), p. 33-46.

Marcadon, J. (1998). L'évolution récente de l'activité maritime et portuaire dans les pays de la Baltique. Bulletin de l'Association de géographes français: la nouvelle Europe médiane, Vol. 4, p. 428-436.

Marcadon, J. (2004). Géoéconomie des détroits danois. Cahiers de géographie du Québec, Vol. 48, 135, p. 289-310.

Mezhevich, N. M., Kretinin, G. V., Fedorov, G. M. (2016). Economic and geographical structure of the Baltic Sea region. Baltic Region, Vol. 3, p. 11-21.

Pourchasse, P. (2010). Le dynamisme des petits ports de l'espace baltique au XVIIIe siècle. Rives méditerranéennes, Vol. 35, p. $99-115$.

Radvanyi, J. (2017). Quand Vladimir Poutine se fait géographe... Hérodote, Vol. 166-167, p. 113-132.

Rozmarynowska, M. (2012). LNG import terminals in Baltic Sea Region - review of current projects. Baltic Rim Economies, Vol. 6, p. 21. Available at: http://eurobalt.org/wp-content/uploads/2012/12/BRE\%206-2012\%20web. pdf [accessed 15 October 2020].

Serry, A. (2019). Containerisation in the Baltic Sea region: development, characteristics and contemporary organisation. European Spatial Research and Policy, Vol. 26, No 1, p. 9-25.

Thorez, P. (2001). Les enjeux portuaires de la Russie en mer Baltique. Territoire en mouvement, Vol. 10, p. 49-59.

Vaneeckhaute, C., Fazlia, A. (2020). Management of ship-generated food waste and sewage on the Baltic Sea: A review. Waste Management, Vol. 102, p. 12-20. 


\section{UOSTO PERTVARKA, ATSKLEIDŽIANTI BALTIJOS JÜROS REGIONO RYTŲ IR VAKARŲ IŠSKIRTINUMA}

ARNAUd SERRY

Normandijos Le Havro universitetas (Prancūzija)

\section{Santrauka}

Baltijos jūros regionas yra ypatinga erdvė, kur ypač svarbūs uostai, jūrų transportas ir visa laivybos grupè. Baltijos jūra yra viena labiausiai apkrautų jūrų pasaulyje, jūrų transportas prisidèjo prie šio regiono klestejimo. Žlugus Sovietų Sajungai, Baltijos jūra atgavo savo, kaip kontaktinès ir tranzitinès zonos, vaidmenį. Rytinès pakrantès atverimas rinkos ekonomikai paskatino jos jūrų sistemos atnaujinimą, kuri metams bėgant niekada nebuvo pagrindinis regioninès integracijos elementas. Kalbos apie Baltijos vienybę dažnai grindžiamos jūrinès padèties ir prekybos jūra svarba, tačiau laivybos pramonèje egzistuoja didžiulè regioninè įvairovè. Šiais laikais naujos specializacijos kryptys, nauji sprendimų priėmèjai uostuose Baltijos uostams kelia naujų lūkesčių ir problemų.

Straipsnyje atskleidžiama, kaip šiame ypatingame Baltijos kontekste sąveikauja uostai ir jūrininkai, dalyvaujantys vykdant regioninę plètrą ir integraciją. Jūrų ir uostų veiklą ribotoje Baltijos erdveje labiau veikia konkurencija, o ne papildomumas, daugialypè analizè, o ne regioninis vienodumas. Taigi Baltijos jūros regiono uostai, Baltijos šalyse išsiskiriantys savo dydžiu ir dažnu atveju gabenantys Rusijos žaliavą, gerokai skiriasi nuo Šiaurès ar Švedijos uostų. Skandinavų uostai yra nedideli ir orientuoti ị savo vidaus rinką. Jūrų transporto srautai, būdingi šiam regionui, kur didžiausią įtaką daro Rusijos Federacijos politika, greičiausiai labai paveiks regionų ekonomikos dinamiką, kaip ir regioninè bei geopolitinè diplomatija ties šia rytine Europos Sajungos ir Rusijos Federacijos siena.

PAGRINDINIAI ŽODŽIAI: Baltijos jūra, uostai, jūru transportas, regionalizacija.

JEL KLASIFIKACIJA: N74.

Received: 2021-09-06

Revised: 2021-09-24

Accepted: 2021-10-05 